\title{
Teaching English Language in a Typical Nigerian Secondary School: A Review of Twenty Years Pedagogical Experience
}

\author{
Iyekekpolor, O.M \\ Department of Arts Education, Taraba State University, Jalingo
}

\begin{abstract}
The role of the English Language in the development of the Nigeria as a country is major and crucial to the fulfilment of SDG 2030 goal in the nation as a whole. The English language is used for education, trade, unity and link with the entire world. Lack of proficiency in English language therefore is equivalent to illiteracy or worst still poor educational achievement; consequently, the Nigerian child will find it difficult to compete in the world of work and employment. This paper highlights the challenges facing the teaching and learning of English language in secondary schools: facts are drawn from the researcher's over twenty years of teaching English language in a typical Nigerian secondary school that feature students from the six geo-political zones of the country. Stakeholders of education in Nigeria must work tirelessly to ensure success in the acquisition and learning of the English language. The English language has incontrovertibly become the second language (L2) in Nigeria and at the secondary level, the language of classroom interaction: it is therefore essential that English language learners (ELL) at this level attain high level of competence.
\end{abstract}

Keywords: SDG (2030) Sustainable Development Goals; SL-Second language; ELL English language learners DOI: $10.7176 /$ JLLL/77-01

Publication date:March $31^{\text {st }} 2021$

\section{Introduction}

This paper positionally examines the challenges of English language teaching in secondary school in a typical Nigerian classroom. English language is the official language of Nigeria. English as an official language has been allocated functions as the language of the media, education, politics, and legal drafting etc. In 1946 constitution of colonial administration first made English language the official language of Nigeria and as the language of colonial administration. On regaining political independence in 1960, English was still adopted as the official language for the country. The 1979 constitution went further to approve the use of English language at the National and State Houses of Assembly; alongside any of the three major Nigerian languages: Igbo, Hausa and Yoruba or language of the state in question only and only when adequate arrangements have been made to their use. English as the official language is the language used by government functionaries in carrying out instructions and functions in government offices (National Open University of Nigeria, 2014). It is the most profound of the legacies of the British government in the country. It remains principally the language of commerce, international relations, unity and of course education. Graddol (1997) cited in Ugwuadu (2014) refers to it as 'a world language'. Trade with other parts of the world would be a near impossibility or a herculean task without this all-important language. It is the language that harnesses various cultures and races in so wide a country together. Ugwuadu (2014) posits that English language makes communication possible among the diverse ethnic groups in Nigeria.

The overall philosophy of Nigeria is to live in unity and harmony as one indivisible, indissoluble, democratic and sovereign nation founded on the principles of freedom, equality and justice; promote inter-African solidarity and world peace through understanding (National Policy of Education,2013). Education invariably is one way of actualizing this philosophy as a tool for development. English is realized as an important tool to actualize functional education, hence the medium of instruction from the fourth year in the primary is officially the English language (NPE, 2013 P.9 Sect19.f). The English language as important and core to the survival of the nation Nigeria, and meeting up with SDG 2030 goal, learners at the secondary school level in Nigerian are below proficiency. Language learning and acquisition involves mastery of the four basic skills: listening, speaking, reading and writing; weakness in any of the aforementioned, is similar to incompetence in the use of English language. Concerted efforts need to be employed by learners, teachers, parents, administrators and the society to facilitate English language learning.

English language has a lot of varieties - there is the Australian English, American English, and British English to mention a few major ones. Specifically, Nigeria adopted the British English. Worthy of note is that before a language can be learnt, it must have certain qualities such as orthography and literature. The variety of English spoken and written by many secondary school students in Nigeria falls below this expectation. It can be referred to as Nigerian English Accent (NEA) which differs from the Received Pronunciation (RP). The RP is the pronunciation of standard British English based on the speech of the educated speakers of southern England. It is the recommended model for higher education to use in the classroom and the model that sums up and put the varieties of the English language together Oloko (2009). Consequently, when students are faced with examination where they are expected to prove the level of their competence in English language, the result is failure. It is 
baffling to see a student pass out of secondary school and could not read fluently, write legibly or communicate effectively, such has not then acquired functional education to make him/her cope in the society, neither can such contribute to the development of his/her immediate environment needless the country as a whole. Adesulu (2014) laments the critical state of students' performance in English language in external examinations - West African Examination Council (WAEC) and National Examination Council (NECO), the view echoed the fears of the examining bodies and the unseeming solution when he spoke through a national newspapers Vanguard thus:

'The poor performance in external examinations, especially in Secondary Schools Certificate Examination (SSCE) and the General Certificate of Education (GCE) examinations by students, has become a source of worry to stakeholders in the education sector, especially in view of the nation's goal to be one of the world's top 20 economies by 2020 . Recent statistics released by the two examination bodies show that the standard of teaching and learning in schools have continued to wane at an alarming rate. The poor performance of students in WAEC and NECO exams in recent times, has resulted in an average failure rate of 72 per cent, 74 per cent, 74 per cent and 75 per cent in 2008,2009,2010 and 2011 respectively. Similarly, the May/June SSCE 2010/2011 examination results show that only 451,187 candidates of 1,351,557 who sat for the exam obtained credit in English Language while 560,974 obtained credit in Mathematics. The results of 77,168 candidates who sat for the exam were withheld for their alleged involvement in examination malpractice. While NECO 2010 reveals that a total of $1,143,169$ candidates registered for the examination, 1,132,357 actually sat for the examination. A breakdown of the results shows that only 244,456 candidates passed English Language at credit level while 279,974 passed Mathematics. The Registrar and Chief Executive of NECO, Professor Promise Okpala, who exonerated the examination bodies of the mass failure, blamed it on the quality of teaching in schools, saying unless there is improvement in teaching and learning in schools, there is little the examination bodies could do to salvage the already bad situation. According to him, less than average of 30 per cent out of the candidates passed at credit levels in the two core subjects - Mathematics and English Language - for the past five years. The Minister of Education, Chief Nyesom Wike, equally expressed displeasure at the students' poor performance, noting that less than 30 per cent of over a million students, who sat for the examinations within the last six years, obtained credits in five subjects, including English Language and Mathematics. Toying with the jewel: Many have described the rot in the education system as toying with the nation's priceless jewel. "Education is everything; the jugular vein of any nation is the education sector. Once the sector collapses, the collapse of the entire system is imminent," said an economist. He blamed the all-pervading system failure across all sectors on the failure of the education system. "The ill-educated engineers construct bad roads. Likewise, the ill-educated medical doctors are not doing well in the health sector," he said.' (Vanguard Newspaper, February, 2014)

The need then arises to review the factors that encourage the poor performance of secondary school learners in this core subject with a view at finding possible solutions. Omodiaogbe echoed by Ogungbe (2008) laments that the standard of English language has fallen at all levels of the school system and in all walks of life. The question then arises, what is the source of the variety of English language spoken and written by these students? What is the role of the students in the poor performance in English language? What is the role of the government, school administrators and society in the poor performance of students in English language? What is the role of the English language teacher in the poor performance of English language today? Can the Nigerian community achieve the SDG 2030 goal of quality education?

\section{English language teaching and learning at the secondary school level}

The broad goals of the secondary school education are to prepare the individual for useful living within the society and for higher education (National policy of Education,2013 p.11). To realize these goals, English language is categorised as one of the core subjects at the junior secondary and senior secondary levels. Most of the textbooks used by students (apart from textbooks meant for specific languages) are written in English language, in the humanities, sciences, technical and business fields. The language of instruction in classrooms remains English language (peculiar language classes exempted) the language of interaction between student of non-native dialect is English language. Though, this trend is fast dying out in the schools today. Many schools in the country source for students from their immediate environment, parents are not at ease to send their students far away from their reach as a result of various crises bedeviling our dear nation. In the past, standard schools were not common in the nation. Parents travel far to get value for their money as far as education of their wards/children is concerned. Reverse is the case today as grade schools with qualified education are everywhere. The implication of this to English language teaching and learning is that students show more loyalty to their dialects rather than English language. Practice the saying goes, makes perfect. The language though a- not-do- without, yet the failure rate is high. This sad trend can be accrued to many factors both internal such as - student related, teacher related and external such as: government/school administrators related, parent related and environment related factors. Oyetunde \& Muodumogu (1999) stated that many people believe that the decline in educational standards in Nigeria has a lot to do with the quality of English teaching and learning. 


\section{The role of students in the failure of English language in Nigeria}

Over the years, it has been discovered that students lack basic textbooks in English language. This factor can be linked to the parents at the same time. The fault may not entirely be theirs (parents) however, but rather carelessness on the part of the student who fails to take proper custody of the books, some even vandalize the money given them to procure books! In a comprehension/summary class for instance, a student who always giraffe before he /she gain view of the passage to be read in the class, cannot answer questions based on the passage effectively. The student will find it difficult to identify, topic sentence differentiates it from support sentences. It would be difficult for such to easily read and answer summary questions. Nearness to a passage aids its understanding. Students reading pace differ as well, in sharing of textbook during reading exercise in the class places certain students at a disadvantage. Students who lack textbooks are not be able to go over a treated passage or go the extra mile of treating other passages available the textbook. Some students lack textbooks until the second or third term of a session. Imagine a student in the secondary school without common dictionary! How does such a child get clue to word meaning, how will such a child find answers to assignments on Test of Orals, how will such a child develop word power, the imagination is endless. There are students who lack exercise books to copy notes in the class, some fail to write correctly or not even write at all what the teacher writes on the board such a student has nothing to fall back on for revision when examination approaches, coupled with the fact that textbooks are lacking - what I hear I forget, what I write I remember, the faintest pen is better than the sharpest brain.

Lack of fundamental knowledge of basics of English language such as of the eight parts of speech in English is another problem. The part of speech in English language is a concept taught from the upper primary level. Sad enough, some students at the senior secondary two and three cannot define or differentiate between adjectives, adverbs or identify prepositions in sentences. How can such identify grammatical class or grammatical function of words or answer questions on lexis and structure successfully? Students do not have the commons knowledge of articles in English grammar or the position of modifiers, order of adjectives etc. The use of punctuation mark is another plaque in secondary school student's English language learning. Students cannot differentiate between the end-punctuation marks and the in-punctuation marks, as a result produce incomprehensible write-ups. Closely linked to the problem of the use of punctuation marks, is the fact that many students have poor orientation of the hand-writing skill, therefore they write illegibly. Students mix up the upper-case letters with the lower-case letters. When teachers write sentences on the board beginning with capital letters, students write theirs beginning with small letters. After an end-punctuation mark, the word that follows ought to begin with an upper-case letter, student do not take note of this. Students at times write questions in form of statements, due to absence of question marks after such interrogative statements. When words are contracted for example; 'do not' changes to 'don't' the presence of omission mark conventionally known as apostrophe is needed, students contract words without the use of such indicative punctuation marks. Quotation marks are the key to tag questions, if a student does not possess the needed understanding of this punctuation mark, he/she will not be able to answer questions based on tag.

A lot of inter-lingua interference from the native language (dialect) of students is revealed in both written and spoken English. Students transliterate while writing thereby giving a different meaning from their intended meaning. Under grammar, particularly ordering of words in some Nigerian languages differ from the way words are arranged or can be manipulated in English language. In certain expressions, Yoruba language for instance, a speaker says 'o pe de lati oja lana' directly transliterated is 'he late came from market yesterday'. The English language correct translation is 'he came back late from the market yesterday' these expressions are similar but there is difference in the order of words, the transliterated arrangement is not acceptable by English language grammatical standard. Another example in Yoruba language is the expression' inu mi dun lati ri yin' the transliteration is 'my stomach is very sweet to see you' this is a totally different meaning from the intended meaning - which is 'I am so glad to see you'. The harm that can be done by lack of competence in English language is limitless. Certain phonetic sounds of English language do not exist in Nigerian languages. Therefore, students find it difficult articulating such phonetic sounds. A typical Hausa language speaker does not have the consonant sound/p/ in his orthographical symbol rather has /f/ therefore he articulates the word 'people' as 'feofle' or 'politics' as 'folitics'. An Igbo language speaker interchanges the consonant sound $/ 1 /$ for $/ \mathrm{r} /$ and vice versa. Hence will pronounce 'Lagos'as'Ragos'. A Yoruba language speaker from a place like Osun state does not have consonant sound /ts/ rather has /s/ or /sh/therefore words such as 'chair' 'church' etc are pronounced with the sound /s/ in place of /ts/ or /sh' ;'sia' ;'shursh'. The word 'think' is pronounced as 'tink'; 'this' as 'dis'; 'thick' as 'tik';'van' as 'fan'; 'vim' as 'fim'. Certain words in English language are produced without an intervening vowel sound, speakers of English language in Nigeria hardly have words like this. Words like 'little' /litl/ are then produced as /litu/, while words where certain consonant sounds are to be silent are loudly articulated for instance 'often' becomes 'oftun','comb' becomes 'combu'; the words 'hour', 'honour', 'home' have the letter ' $h$ ' silent but this is articulated strongly by second language learners. The examples are endless. The implication of this is that students with inter-lingua interference problem would perform poorly in Test of Orals which is part of the assessment at the final examination in the secondary school. Sad enough, when English language teacher attempt to articulate 
these sounds in the classroom during oral-aural exercises, students make light of it and instead of imitating the teacher, laugh it off and bask in their ignorance. There is absurd and sometimes embarrassing mispronunciations of English words by those who use English as a second language submits Egwuchukwu (2006). Linked to the problem of inter-lingua interference is the loyalty students pay to their dialects whose consonant, vowel sounds, and accents are at par with the Received Pronunciation. As a result of limitation in the mix of students found in schools today (as stated earlier), students no longer communicate effectively in English language.

Many students are insincere when assignments are given to them. As earlier stated, some do not have materials to use while some who have are lazy and cumbered with one form of frivolity or the other. When such tasks are repeated in examinations, certainly, such a student would have nothing to write. A very ready example is assignments given on Registers- meaning of peculiar words in particular fields. Some students feel the words are so many and would not attempt to check them up in the dictionary but copy from friends; such answers cannot be internalized and transferred to long term memory to recall when the need arises for its usage in examination. It is worthy of note that for learning to be effective the learner must practice exercises, provide answers to questions of various types. Egwuchukwu (2006) stressed that lack of interest and seriousness on the part of the students is an impediment to the learning of the subject and this has brought about great failures in English language examinations over the years. Students pay less attention to the study of English language than they pay to other subject. As a matter of fact, students feel there is nothing to read in preparation for English language examination.

\section{The role of teachers in the failure of English language in Nigeria}

Closely following student related factors are the teacher related factors. Pivot among these is poor knowledge of content coupled with methodology. It is sad to note that some of the teachers of English language lack the sufficient cognitive ability to teach the subject. It is one thing to have the knowledge of something it is another to possess the skill of imparting the knowledge to others English language teachers lack the ability to cultivate effective composition skills, increase vocabulary awareness, promote efficiency in reading and help students to gain control of grammar. This may be due to poor grooming in their various tertiary institutions, effect of corruption that has eaten deep into the Nigerian system not teaching English language as a matter of necessity not because they are professionals (this will be looked at later). It is not possible to give what you do not have. Teachers lack the necessary knowledge of grammar, test of orals, demand of continuous writing, correct spelling of words, read poorly, lack the knowledge of the role of phonological awareness, phonics, structural analysis, fluency, vocabulary and comprehension in learning to read and spell; cannot differentiate between a phrase, clause and sentence, lack the ability to articulate the various phonetic sounds of English language hence will not be able to impart the knowledge and the chain continues. The level of education, sophistication and exposure of the teacher is above that of the student. He/she is expected to be a model to the student. The school environment comprises of the very fluent, average, and very poor speakers of English language, but each student is unique with abilities and potentials that can be manipulated by the sensitive teacher to achieve the goal of teaching and learning in an English language class. Ubahakwe1988 echoed in Oyetunde and Muodumogu (1999) stressed that Nigerian English language teachers are not thoroughly grounded in content and methodology. An NCE holder with English as a teaching subject walks into an office in search of job is unable to write an application letter successfully! What then did he/she teach during the period of internship (teaching practice). Teachers hardly engage in self-improvement programs, yet the language has to be taught very well. Ikeobi, 1995 cited in Iyekekpolor \& Omenka (2007) emphasized that qualified teachers are in short supply. The dearth of qualified English language teachers is a clog in the wheel of progress of the teaching and learning of English language (Ikeokafor, 2006).

Teachers' pattern of assessment is another issue under teacher-related factor. English language teachers are overwhelmed with much work in comparison to teachers of other subjects. The English language cannot be taught effectively without constant giving of exercises, drills, assignments, and class work to students. The problem under this is divided into two. There are teachers who endeavour to bombard students with series of assignments, class work and projects. These group of teachers do not mark these assignments and give feed back to their students, as a result the students cannot actually tell if they are on the right part or not. The role of feedback in English language testing cannot be overemphasized. There are teachers who seldom give assignment to students, they teach and that is all about it. There are teachers who teach about the language and not the language. The teacher saturates the learners with definitions, rules of usage, theories of grammar rather than focusing on the practical usage of the English language in different contexts: on the street, in the marketplace, on the farm, shops hospitals, worship centers and other places where people congregate for business, entertainment, communal or social activities. It is practice in such pragmatic use of language that can bring about the much-desired functional competence in English language, Amore (2009) submits.

There are two goals of the secondary school teaching. One is to teach with examination in view and the other is to teach with the mind of truly transforming the child. Teaching with examination in view always come to play when teachers suddenly realize that the time has closed up on them, (either as a result of negligent on his/her part as a teacher, strike action or prolonged stay of students at home due to crisis) and the examination of students is at 
the door. At such a time the teacher teaches solely focuses on what he/she feels might face the students in the examination. In other not to be accused of having not taught the students, the teacher speedily runs over certain topics. This approach is not the best for lasting knowledge. On the other hand, there are teachers who teach with the mind of teaching the entire knowledge as specified in the curriculum and even go the extra mile by teaching what they feel the student need to have knowledge of. Such a teacher begins from what the student does not know to what he/she has been assigned to teach. A student under such tutelage would rank among equals in the society. Under Test of Orals examination today, questions are not set on 'intonation-fall/rise tune'. An English language teacher that is worth its salt would certainly teach this practically to students with examples knowing fully well that it is the key to fluency in reading and students who might eventually find themselves in broadcasting would find such knowledge essential. Students are not asked to transcribe words in English language examinations neither are they required to draw vowel chart or table of consonant sound classification, but these are the pointers to answering questions in paper three of English language examination. English language is an applied subject. All that a student has learnt from the cradle in English language is tested when he/she is to be considered as one worthy of having a certificate in the subject or not. Of sad note are corrupt English language teachers, who have thrown nobility of their profession to the wind. They allow themselves to be bought over by wealthy parents. When such parents realize that their wards/children are not performing well in the subject and it is a criteria for promotion, such parents give some fund to teachers and these unashamedly boost the scores of such dullards and they are qualified for promotion only to fail out at the end, even when they scale though the external examination by virtue of malpractice, when it comes to exercising the brain in the place of job, the end would justify the means. There are English language teachers who engage in illicit affair with students and pay back with scores!

\section{The role of school administrators in the failure of English language in Nigeria}

School administrators are not exempted from the ache of mass failure in English language. Indiscipline is a cankerworm that has eaten deep into the fabrics of schools today and unfortunately, the trend seems to have overpowered the school administrators. Students report to school at will, those in the boarding house stay in their hostels during lessons, some who do not do their assignments are spared, students behave rudely, insult and assault their teachers and go free. Effective teaching and learning will constantly be a mirage in such a school environment. Some hooligans are even protected by certain powers in the school because they have what can be referred to as godfathers who possibly have been bought over by wealthy parents. School administrators do not reward hard work. When English language teachers put in their best and students perform well, such efforts go unrecognized. At the point of admission in schools, administrators are bought over by rich parents of unqualified students. Credit/merit in English language is one of the criteria before a pupil gains admission into the secondary school. Unfortunately, students who cannot read are admitted into the secondary schools without any plan to remediate their poor ability in English language. Relevant and current textbooks are not provided in the school libraries, teaching aids are not given to teachers when they make request under the guise of lack of fund, language laboratory is a toothpick issue in schools. English language teachers are not allowed to go for conferences even when administrators receive notification for such early enough. School administrators do not put policies in place to enforce communication in English language as a result, students interact mainly in dialects and pidgin English which have negative effect on their official communication.

\section{The role of the government in the failure in English language in Nigeria}

The government bears a portion in the failure of English language recorded in the country. Generally, it is a known fact that a lot of non-professionals have found their way into the Nigerian classroom - no thanks to the rate of unemployment in the country. Many people who are teachers today, do not have passion for teaching. Teaching was only resorted to as the last option to keep body and soul together. When such even find themselves in the classrooms, less effort is made at self- grooming to meet up with the demands of the profession because they feel that they are not in the right place and at any opportunity would throw the job away for a more lucrative one. Aside from the issue of English language teaching, the teaching profession is the most porous of the profession in the country, Nigeria. How we pray for the professionalization of the teaching job so there can be some sanity in the classrooms.

The government is the sole owner of non-private schools. Little effort is made at employing English language professionals to teach the subject. In some government schools, English language teachers do not exist. In some places where they exist the population of the students overwhelms the English language teacher so that no matter his/her effort, a little impact can only be seen on the fittest of the students. Some schools can only boast of just one English language teacher covering junior secondary 1,2 and 3 the same in the senior secondary 1,2 and 3. Nigerian government appears to be chasing the shadows. What then is the place of campaign against examination malpractice or setting up of committees to investigate poor performance of students in English language? A government owned school would employ temporary teachers to teach core subject like English language and there are graduates of English language education out there on the streets with no job, what a malady! Schools owned 
by the government ought to enjoy some subvention or aid in form of supply of current books to the school libraries, building and equipping language laboratories, organizing refresher courses for English language teachers, mandating school administrators to sponsor English language teachers to these courses, sponsor on the job training of English language teachers, motivate hardworking English language teachers, unfortunately these laudable goals are yet on dreamland.

\section{The role of parents in failure in English language in Nigeria}

Parents bear a grunt of this blame well. There are parents who do not order their priorities right. They fail to pay the school fees of their wards/children at the right time. Such students are sent away from school from time to time in the course of this, they miss out on important English language lessons and such lessons would not be repeated. In some parts of the country, some parents feel that students only need to go to school when promotion examination is at the corner. Such parents ask their wards/children to follow them to their farms and assist them in their businesses under the guise that it from such ventures the school fees are paid. Parents fail to procure basic textbooks in English language for their children/wards either due to poverty, giving birth to many children and as a result not able to satisfy their educational demands or nonchalant attitude. Parents do not communicate in English language to their children/wards at home so that the only contact students have with English language is in the class.

\section{Conclusion/recommendations}

A thorough look at the factors stated above calls for an urgent solution to put an end to the poor trend of mass failure in English language. English language teaching in Nigerian secondary schools should be geared towards the attainment of the beliefs in the philosophy of education and SDG 2030 goals by equipping the student to have a functional education and quality education for personal development and in turn be an instrument for national and international development; all hands of stakeholders must be on deck for this to be accomplished. Parents/guardians, government, school administrators, teachers and of course the students, need to work for a common goal -war against failure in English language, we can, and we shall.

In the light of the above:

Parents should be disciplined enough to give birth to children their resources will be able to effectively cater for academically.

The government should endeavour to give automatic employment to English language education graduates after thorough interview and post such to schools. As a matter of urgency, it should take stock of schools where English language teachers do not exist and post such ones there after which it will ensure that sufficient number of English language teachers is in various schools. The maximum ratio of English language teachers to students should be ratio 1 teacher to 10 students for effective teaching, learning and assessment to take place in English language. Non-graduates of English language education should be stopped immediately from doing more harm to the teaching and learning of the subject. Graduates of English language who are on the teaching job without educational qualification should proceed on a course that will expose them to the methodology of the subject. Qualified practicing English language teachers should go for refresher course on regular basis to keep them abreast of the students. Iyekekpolor and Iyekekpolor (2014) opined that entrance into the teaching of English language should be under strict control, that non-English language teachers should not be allowed to teach the subject and those currently teaching must show evidence of attendance of refresher courses.

The government should equip the school libraries with relevant and current books in English language. It should live up to its expectation by building and furnishing English language laboratories in schools.

The government should investigate the state of English language teaching in private schools and set minimum standard for the teaching of the subject which will be closely monitored by reliable English language education specialists from tertiary institutions at intervals.

Amidst other efforts, the government should endeavour to professionalize teaching, place teachers on a special salary scale and give special allowance to teachers who handle core subjects with many students like the English language. This peradventure would curb corruption and motivate the teachers to work faithfully and effectively.

The school administrators should endeavour to increase the tone of discipline in schools. Enforce policies on admission, resumption of students to school and possess zero tolerance for any trace of hooliganism, cultism and frivolity.

Teachers should develop themselves through reading and sourcing for current materials on English language teaching development, vary their methodology and discover the strengths and weaknesses of their students so as to determine how to intervene for the better. Teachers should improve on their assessment pattern and ensure feedback is given to students after assignments. Administer impromptu class test so that students can be ready always and truants can sit up. Teachers should be loyal to their profession and should refuse to be part of the corruption bedeviling education sector in the nation.

Students must determine to succeed. 'I can can, I cannot cannot' the saying goes. The potential is there and 
if parents, government, administrators and teachers are awake to their duties, there is no hiding place for the erring student. He/she must tow the path of success and by the grace of God failure in English language in secondary schools in Nigeria, will be 'Once upon a time...'

\section{References}

Adesulu, D. (2014). Experts proffer solution to failures in Mathematics and English. Vanguard News Paper, Nigeria. February 20th, 2014.

Amore, K.P. (2009). Teach the language and not about the language: A functional strategy to teaching English as a second language. The Journal of Communicative English, 5(2), 20-31

Egwuchukwu, I. (2006). Repositioning language education in Nigeria: A case of English language. Multidisciplinary Journal of Research Development. 7(2), 109-113.

Federal Republic of Nigeria (2013). National policy on education (4th edition).Abuja, Nigeria: NERDC

Iyekekpolor, O.M. \& Iyekekpolor, S.A. (2014). Assessment of serving teachers' expectation on effective English language teacher education programme in the 21 st century. TSU Journal of Education Research and Production. 1 (2), 13-17.

Iyekekpolor, S. A. \& Omenka, J. E. (2007). The teacher factor in the universal basic education (U.B.E) in Nigeria: Issues and challenges. Multidisciplinary Journal of Research Development. 9 (2), 27-32

Ogungbe , E. O (2008). Aspects of nominal expressions in written English usage of first year undergraduates of IBB university, Lapai. The Journal of Communicative English 4 (6), 63-84.

Oloko, M.J. (2009). A contrastive analysis of english phonology and the phonological patterns of Nigerian English speakers. Journal of Communicative English, 1 (1), 1- 19

Oyetunde, T.O. \& Muodumogu, C.A. (1999). Effective English language teaching in And secondary schools. Some basic considerations and strategies. Jos: Conference on educational improvement.

Ugwuadu, N.G. (2014). The educational value of learning English language in the society.

TSU Journal of Education Research and Production. 1, (2), 1-6. 